6338

Research Article

Journal of Extension Education

Vol. 31 No. 3, 2019

DOI:https://doi.org/10.26725/JEE.2019.3.31.6338-6342

\title{
Spread and Acceptance of TPS 5 Paddy Variety in Kanyakumari District of Tamil Nadu
}

\author{
R. Premavathi ${ }^{1}$ and R.Sasikala ${ }^{2}$
}

\begin{abstract}
The present research has been undertaken to study the spread and acceptance of TPS 5 Paddy Variety in Kanyakumari District of Tamil Nadu. Ramapuram, Andarkulam and Manavalakurchi villages of Agastheeswaram and Kurenthenkode blocks of Kanyakumari district were purposively selected based on more area under TPS 5 rice cultivation. Sixty rice growers were selected from the villages based on random sampling method. The data were collected using pre-tested interview schedule and analyzed by using appropriate statistical tools. The results revealed that most of the respondents belonged to old age and had followed agriculture as a primary occupation. Most of the respondents had high level of extension participation. The analysis of extent of adoption indicated that seventy five per cent of the respondents adopted TPS 5 variety in Kannipoo season. More than eighty per cent of the respondents had adopted recommended seed rate, age of seedling and spacing. Non availability of quality seeds and machineries in time, high weed infestation and improper usage of pre-emergence herbicide, lack of knowledge on application of recommended fertilizer and pest management practices were the major constraints encountered by the respondents.
\end{abstract}

Keywords: Technology Adoption; TPS 5 rice variety; Constraints; Tamil Nadu

\section{INTRODUCTION}

In Tamil Nadu, around 153 rice varieties have been released and among them 86 are short duration varieties. In Kar season short duration rice varieties like ASD 16, ADT 43 and ADT 45 are grown by the farmers in Tamil Nadu. It is necessary to enhance the yield strata and narrow the yield gap for further increase in rice productivity.

Rice is one of the major crops being cultivated in Kanyakumari District of the state. It occupies more than 12000 ha in two seasons (Kharif and Rabi) of the year. ASD 16 is the only rice variety cultivated by the farmers in Kannipoo season. Low yield due to lodging, occurrence of pest and diseases (leaf folder, stem borer and tungro) and poor grain filling are the major constraints reported by the farmers while cultivating ASD rice varieties. So, farmers need alternate high yielding, nonlodging, pest and disease resistant variety. This necessitates identifying suitable replacement for ASD 16 that circumvent the stagnancy

${ }^{1}$ Associate Professor $\& 2$ Assistant Professor, Directorate of Extension Education, TNAU, Coimbatore- 641003.

Received : 25-11-2019; Accepted : 14-02-2020 
in productivity besides holding the key traits of the old variety. In this context, efforts were made at Agricultural Research Station, Thirupathisaram of Tamil Nadu Agricultural University, to evolve high yielding, nonlodging rice variety having non-shattering bold grain type with resistance to major pests and diseases. It has released TPS 5 rice variety during 2013 which is having almost similar duration of existing ASD 16. Also the new variety produces 10-15per cent of higher yield, non-lodging, tall growing and moderately tolerant to most of pest and diseases. In this background, the present study assessed the spread and acceptance of TPS 5 rice variety in Kanyakumari district.

\section{METHODOLOGY}

Kanyakkumari district was selected as the study area based on more area under TPS 5 rice cultivation. Kanyakumari district consists of nine blocks, out of which Agestheswaram, Rajakamangalam and Kurenthenkode block of Kanyakumari district were selected because of more area under rice cultivation. Three villages were selected from the selected blocks viz., Ramapuram, Andarkulam and Manavalakurchi. Samples of 60 rice growers were selected from selected villages based on proportionate random sampling method. Data were collected with the help of a well structured pre-tested interview schedule and analyzed with suitable statistical techniques.

\section{FINDINGS AND DISCUSSION}

\section{Adoption of rice variety TPS 5 and management technologies}

The results revealed that majority of the respondents (75.00\%) adopted TPS 5 variety followed by ASD -16 (25.003\%)

Table 1.

Distribution of Respondents according to their Adoption of TPS 5 Rice Production Technologies

\begin{tabular}{|c|c|c|c|}
\hline \multirow{2}{*}{$\begin{array}{l}\text { SI. } \\
\text { No }\end{array}$} & \multirow{2}{*}{ Particulars } & \multicolumn{2}{|c|}{ Adoption } \\
\hline & & Number* & Percentage \\
\hline 1. & $\begin{array}{l}\text { Variety } \\
\text { Thirupathisaram rice TPS-5 } \\
\text { ASD } 16\end{array}$ & $\begin{array}{l}45 \\
15\end{array}$ & $\begin{array}{l}75.00 \\
25.00\end{array}$ \\
\hline 2. & $\begin{array}{l}\text { Season } \\
\text { Kannipoo }\end{array}$ & 60 & 100.00 \\
\hline 3. & $\begin{array}{l}\text { Seed rate } \\
60 \mathrm{~kg} / \mathrm{ha}\end{array}$ & 56 & 93.33 \\
\hline 5. & Age of seedling $18-22$ days & 49 & 81.66 \\
\hline 6. & Spacing $15 \times 10 \mathrm{~cm}$ & 51 & 85.00 \\
\hline 7. & $\begin{array}{l}\text { Weed management } \\
\text { Usage of Pre emergence herbicide }\end{array}$ & 23 & 38.33 \\
\hline
\end{tabular}




\begin{tabular}{|c|c|c|c|}
\hline \multirow{2}{*}{$\begin{array}{l}\text { Sl. } \\
\text { No }\end{array}$} & \multirow{2}{*}{ Particulars } & \multicolumn{2}{|c|}{ Adoption } \\
\hline & & Number* & Percentage \\
\hline 8. & $\begin{array}{l}\text { FYM } \\
12.5 \text { tonnes/ ha or Green manure } 6.25 \text { tonnes/ha }\end{array}$ & 41 & 68.33 \\
\hline 9. & $\begin{array}{l}\text { Basal } \\
\text { Phosphorous }-50 \mathrm{~kg} / \mathrm{ha} \\
\text { Potash }-12.5 \mathrm{~kg} / \mathrm{h} \\
\mathrm{ZnSO}_{4}-25 \mathrm{~kg} / \mathrm{ha}\end{array}$ & 16 & 26.66 \\
\hline 10. & $\begin{array}{ll}\text { NPK } & \\
\text { 30: } 0: 12.5 \mathrm{~kg} / \mathrm{ha} & -15-20 \text { DFP } \\
\text { 30: } 0: 12.5 \mathrm{~kg} / \mathrm{ha} & -35-40 \text { DFP } \\
\text { 30: } 0: 0 \mathrm{Kg} / \mathrm{ha} & -55-60 \text { DFP } \\
\text { 30:0:12.5 kg/ha } & \text { - flowering stage }\end{array}$ & 16 & 26.66 \\
\hline 11. & $\begin{array}{l}\text { Foliar spray } \\
\text { Urea } 1 \%+\text { DAP } 2 \%+\text { Murate of potash } 1 \% 2 \text { times } \\
\text { after } 10 \text { days planting }\end{array}$ & 14 & 23.33 \\
\hline 13. & $\begin{array}{l}\text { Early post emergence herbicide } \\
\text { Bispyripac sodium (Nominigold)- 100ml }\end{array}$ & 53 & 88.33 \\
\hline 14. & $\begin{array}{l}\text { Acid soil management in paddy } \\
\text { Dolomite } 150 \mathrm{~kg} / \mathrm{ha}\end{array}$ & 60 & 100.00 \\
\hline 15. & Water management & 58 & 96.66 \\
\hline 19. & $\begin{array}{l}\text { Plant protection measures } \\
\text { Stemborer }\end{array}$ & 31 & 51.66 \\
\hline & Leaf folder & 39 & 65.00 \\
\hline 20. & $\begin{array}{l}\text { Harvesting } \\
25-30 \text { days after flowering }\end{array}$ & 60 & 100.00 \\
\hline 21. & Machine harvesting & 48 & 80.00 \\
\hline
\end{tabular}

in Kannipoo season (Table 1). More than eighty per cent of the respondents adopted recommended seed rate, age of seedling and spacing due to interventions of KVK. Meager percentage of the respondents adopted (26.66 \%) recommended basal and NPK fertilizer application. Indiscriminate usage of fertilizer like DAP and Factomfos (Ammonium
Phasphate Sulphate) up to flowering stage might be the reason for non adoption of recommended fertilizers.

Thirty eight per cent of the rice growers had not adopted weed management practice due to labour scarcity, lack of awareness and poor knowledge of pre emergence herbicide. Lack of awareness and interest on application 
Table 2

Distribution of Respondents according to the Constraints Faced by them in Adoption of Technologies

\begin{tabular}{|c|l|c|c|}
\hline $\begin{array}{r}|c| \\
\text { Sl. } \\
\text { No. }\end{array}$ & \multicolumn{1}{|c|}{ Constraints } & Number* & Percentage \\
\hline 1. & Non availability of quality seed & 54 & 90.00 \\
\hline 2. & Labour scarcity & 48 & 80.00 \\
\hline 3. & Lack of knowledge on application of recommended fertilizer & 52 & 86.66 \\
\hline 4. & $\begin{array}{l}\text { High weed infestation improper usage of Pre-emergence } \\
\text { herbicide }\end{array}$ & 53 & 88.33 \\
\hline 5. & $\begin{array}{l}\text { Non availability of machineries in time like transplanter, tray } \\
\text { and paddy harvester }\end{array}$ & 54 & 90.00 \\
\hline 6. & Pest management especially stem borer and leaf folder & 41 & 68.33 \\
\hline
\end{tabular}

${ }^{*}$ Multiple responses

of foliar spray at panicle initiation stage might be the possible reason for non adoption. More than fifty per cent of the respondents adopted recommended pest control measure for leaf folder and stem borer due to possible regular visits and technological interventions made by KVK officials during the front line demonstration and training programmes. Eighty per cent of them had adopted paddy harvester for harvesting. Most of the respondents expressed that non availability of the harvester in time which might be the possible reason for medium adoption.

\section{Constraints faced by the Rice Growers}

The study reveals that non availability of quality seeds and machineries in time like transplanter, tray and paddy harvester were the major constraints expressed by ninety per cent $(90.00 \%)$ of rice farmers. More than eighty per cent of the farmers expressed that lack of knowledge on application of recommended fertilizers, high weed infestation and improper usage of pre-emergence herbicide and labor security. More than sixty per cent (68.33\%) of them expressed that lack of knowledge on pest management practices especially stem borer and leaf folder.

\section{Suggestions offered}

Majority of the rice farmers suggested that State Department of Agriculture, Krishi Vigyan Kendra (KVK) and Research stations may take necessary arrangements to supply quality seeds for the farmers in time. It was also suggested that training cum demonstration may be conducted on technologies viz., seed production technology and application of soil test based recommended fertilizers. It was also suggested that the KVK scientists should motivate the farmers to go for soil testing and conduct demonstration on soil collecting methods. The KVK scientists and 
Table 3.

Distribution of Respondents according to the Suggestions offered

\begin{tabular}{|c|l|c|c|}
\hline $\begin{array}{c}|c| \\
\text { Sl. } \\
\text { No }\end{array}$ & \multicolumn{1}{|c|}{ Suggestions } & Number* & Percentage \\
\hline 1. & $\begin{array}{l}\text { Arrangement to supply the quality seed for the farmers in time } \\
\text { by officials, Seed Production Department and TNAU }\end{array}$ & 24 & 80.00 \\
\hline 2. & $\begin{array}{l}\text { Training cum demonstration to be given to the farmers on } \\
\text { technologies viz., application of soil test based recommended } \\
\text { fertilizer }\end{array}$ & 52 & 86.66 \\
\hline 3. & $\begin{array}{l}\text { Creating awareness on usage of pre emergence herbicide } \\
\text { application }\end{array}$ & 49 & 81.66 \\
\hline 4. & $\begin{array}{l}\text { Department of Agricultural engineering to take necessary action } \\
\text { to provide machineries in time }\end{array}$ & 38 & 63.33 \\
\hline 5. & Motivate the farmers on farm seed production & 47 & 78.33 \\
\hline
\end{tabular}

${ }^{*}$ Multiple responses

State Department Officials must conduct awareness cum training programs for usage of pre - emergence herbicide application. Apart from this, front line demonstrations should be conducted on farmers fields to encourage them for wider adoption.

\section{CONCLUSION}

Effective introduction of onfarm seed production may be enhanced to enable farmers to produce on-farm seeds especially TPS 5 rice variety within their community in order to alleviate seed shortage. Popularization of TPS 5 rice variety including all packages of practices through Front Line Demonstrations Farmers are to be encouraged to form of Rice Commodity Groups which will help them to find market for their products at profitable rates. 